\title{
Performance Evaluation of Equity Mutual Funds in Indonesia
}

\author{
Irene Rini Demi Pangestuti ${ }^{1}$, Sugeng Wahyudi ${ }^{1}$, Robiyanto Robiyanto ${ }^{2}$ \\ ${ }^{1}$ Department of Management Faculty of Economics and Business Universitas Diponegoro \\ Jl. Prof. Soedarto SH, Semarang, 50275, Indonesia \\ ${ }^{2}$ Department of Management Faculty of Economics and Business Satya Wacana Christian University \\ Jl. Diponegoro 52-60 Salatiga, 50711, Indonesia
}

\begin{abstract}
Keywords:

Adjusted Jensen

Index (AJI);

Adjusted Sharpe

Index (ASI); Equity

Mutual Funds;

Jensen Alpha;

Sharpe Index;

Sortino Ratio;

Treynor Ratio

JEL Classification:

G12, G20

Mutual funds considered as an investment alternative for investors. One type of mutual fund that attracts many investors was the equity mutual funds. Equity mutual fund is a type of mutual funds that most part of the investment consists of stocks in the capital market so the risk rate was higher than the other types of mutual funds. For its different characteristic, the measurement for equity funds performance did not be same with other types of mutual funds. As a stock portfolio, equity mutual funds can be measured by portfolio measurement methods such as Sharpe Index, Treynor Ratio, Jensen Index, Adjusted Sharpe Index, Adjusted Jensen Index, and Sortino Ratio. This study was conducted by using all of those performance measurements as most research in Indonesia was conducted by using limited performance measurements (focusing on Sharpe Index, Treynor Ratio, and Jensen Index). This study aims to evaluated the performance of 42 equity mutual funds available in Indonesia by employing Sharpe Index, Treynor Ratio, Jensen Index, Adjusted Sharpe Index (ASI), Adjusted Jensen Index (AJI), and Sortino Ratio because most previous researches in Indonesian setting disregards ASI and AJI. In general, it was concluded that the SAM Indonesian Equity was the best performing equity fund during the study period. It was further found that most equity mutual fund studied have been well diversified.
\end{abstract}

\section{ABSTRAK}

Kata Kunci:

Adjusted Jensen Index (AJI); Adjusted Sharpe Index (ASI);

Reksa dana saham; Jensen Alpha, Sharpe Index, Sortino Ratio; Treynor Ratio
Reksa dana merupakan alternatifinvestasi bagi kalangan investor. Salah satu reksa dana yang banyak menarik kalangan investor adalah reksa dana saham. Reksa dana saham adalah jenis reksa dana yang sebagian besar investasinya terdiri dari saham-saham di pasar modal, sehingga memiliki tingkat risiko yang lebih besar dibandingkanjenis-jenis reksa dana yang lain. Karena memiliki karakteristik yang berbeda,maka pengukuran kinerja reksa dana saham tidak dapat disamakan dengan jenis reksa dana yang lain. Sebagai portofolio, maka reksa dana saham dapat diukur dengan menggunakan metode-metode pengukuran portofolio seperti Sharpe Index, Treynor Ratio, Jensen Index, Adjusted Sharpe Index, Adjusted Jensen Index, dan Sortino Ratio. Penelitian ini dilakukan dengan menggunakan seluruh pengukuran kinerja tersebut karena kebanyakan penelitian di Indonesia dilakukan dengan terbatas pada beberapa pengukuran kinerja saja (berfokus pada Sharpe Index, Treynor Ratio dan Jensen Index). Penelitian ini bertujuan untukmengevaluasi kinerja 42 reksa dana saham yang terdapat di Indonesia dengan menggunakan Sharpe Index, Treynor Ratio, Jensen Index, Adjusted Sharpe Index, Adjusted Jensen Index, bahkan Sortino Ratio. Secara umum disimpulkan bahwa dengan menggunakan berbagai alat pengukuran yang ada maka reksa dana saham SAM Indonesian Equity merupakan reksa dana saham dengan kinerja yang terbaik selama periode penelitian. Lebih lanjut ditemukan pula bahwa sebagian besar reksa dana saham yang dikaji telah terdiversifikasi dengan baik. 


\section{Jurnal Keuangan dan Perbankan | KEUANGAN}

Vol. 21, No. 4, Oktober 2017: 527-542

Mutual fund is one of the alternative investments in financial assets for the society in addition to deposit, stock, and bond investments (Simforianus \& Hutagaol, 2008). Mutual fund arises because, in general, investors experience difficulties to make their own portfolio investments in securities. The difficulties faced by the investors include the need to conduct various analyses on securities and to continuously monitor the market conditions which is very time-consuming. Another difficulty is the need for relatively large funds to do investment in securities.

Mutual fund is managed by two parties, namely Investment Manager and Custodian Bank. Investment manager (IM) is a company which manages the client's securities portfolio and is responsible for the investment activities which include analysis and selection of investment types, making investment decisions, monitoring investment markets, and taking actions for the interests of it customers. Whereas Custodian Bank is a part of business activities of a bank in the field of securities storage and its administrations (Pratomo, 2001). Thus, the performance of a mutual fund is determined by how the investment manager manages the investors' funds in a securities portfolio.

Mutual fund is able to offer higher long-term potential benefits than savings and deposits. But, it should be realized that basically all investments have risks. Similarly in the mutual fund investment, potential benefits and risks offered by each mutual fund varied, ranging from the lowest to the highest, depending on the type of mutual funds to be selected. There are several types of mutual funds in Indonesia including equity mutual funds, fixed income mutual funds, balanced mutual funds, money market mutual funds, and sharia mutual funds. Each mutual fund has different characteristics. These different characteristics will cause differences in mutual funds performances, for instance, equity mutual funds will tend to have higher risks compared to fixed income mutual funds because equity mutual fund is the mutual funds with the largest portfolio composition in the form of stocks as it has growth objectives (Simforianus \& Hutagaol, 2008). Due to these different characteristics also, the performance analyses of each mutual fund need to be carefully carried out and use appropriate benchmarks (Arisonda, 2013).

Equity mutual funds as a stock portfolio can be measured for its performance using portfolio measurement methods such as Sharpe Index, Treynor Ratio, Jensen Index, and Sortino Ratio. Of all the measuring instruments, the Sharpe Index in the most commonly used and even become standard for industry (Scholz \& Wilkens, 2006; Kidd, 2011b; Bednarek, Patel, \& Ramezani, 2014; Robiyanto, Wahyudi, \& Pangestuti, 2017) since it can be implemented to compare performance among mutual funds (Swinkels \& Rzezniczak, 2009). However, some of these measuring instruments such as Sharpe Index and Jensen Index are perceived as to have weaknesses. For example, Sharpe Index is considered to focus only on variance (Kidd, 2011b), whereas Jensen Index cannot be compared at different market levels (Zulkafli, Ahmad, \& M., 2017). Hence, they need to be adjusted to become Adjusted Sharpe Index (Jobson \& Korkie, 1981) and Adjusted Jensen Index (Zulkafli, Ahmad, \& M., 2017).

In Indonesia, several research on equity mutual funds performance measurements or stock portfolio performance in Indonesia have been performed by Simforianus \& Hutagaol (2008); Simanjuntak (2012); Arisonda (2013); Qomariah, Sari, \& Budiarti (2016). Arisonda (2013) conducted a study on stock portfolio in Indonesia Stock Exchange by using Sharpe Index, Treynor Ratio, and Jensen Index. Arisonda (2013) found that there were no differences in performance measurements using the 3 instruments. Meanwhile, Simanjuntak (2012) examines equity mutual fund performance with sharia mutual fund performance in Indonesia by employing Sharpe Index, Treynor Ratio, and Jensen Index as the measuring instruments. 
Simanjuntak (2012) found that the sharia mutual funds are able to produce better performance than the equity mutual funds. Simforianus \& Hutagaol (2008), with those measuring instruments, found that 56.25 percent of equity mutual funds can generate superior performances during 2002-2007. In contrast to these research, Qomariah, Sari, \& Budiarti (2016) does not utilize the performance measuring instruments but only compares the risks and returns of sharia equity mutual funds and conventional mutual funds. The research found that the sharia equity mutual funds have lower risks compared to the conventional ones.

Research on equity mutual funds that have been conducted in Indonesia tend to use limited measuring instruments on Sharpe Index, Treynor Ratio, and Jensen Index (Arisonda, 2013), and also Sortino Ratio (Simforianus \& Hutagaol, 2008). There is still no research conducted that employed the adjusted instruments such as Adjusted Sharpe Index and Adjusted Jensen Index to avoid bias. Hence, in addition to the utilization of Sharpe Index, Treynor Ratio, Jensen Index, and Sortino Ratio, this study also uses Adjusted Sharpe Index and Adjusted Jensen Index. Jobson \& Korkie (1981), Cvitanic, Lazrak, \& Wang (2007), and Zulkafli, Ahmad, \& M. (2017) stated that the Sharpe Ratio have a weakness and could biased. Pav (2016) stated that the occurence of this bias was led by the noise of time series data. So the use of Adjusted Sharpe Index (ASI) is indispensable in portfolio evaluation (Kidd, 2012; Bednarek, Patel, Ramezani, 2014). The same problem also rise in Jensen Alpha, according Zulkafli, Ahmad, \& M. (2017), Jensen Alpha is not appropriately used to measure performance at different performance levels, hence need an adjustment also in order to make better comparation (Kidd, 2011a). This adjustment held by using systematic risk factors and the results often called as Adjusted Jensen Alpha (Index)/ AJI.

Overall, this study aims to evaluate the performance of equity mutual funds in Indonesia by using various portfolio measurement methods, so can objectively give a suggestion toward the Indonesian equity mutual fund investors.

\section{Portfolios Theory and Mutual Funds}

Markowitz (1952) suggests 2 approaches in the investment portfolio, i.e. the classical approach and the modern portfolio approach. The classical approach emphasizes on efficiency. Markowitz uses mean-variance analysis to form an efficient portfolio, a portfolio that provides the highest return for a given level of risk. Hence, the efficient portfolio of Markowitz is also called mean-variance efficient portfolio. While on the modern portfolio theory approach for investment, it starts with an assumption that investors have spent some amount of money on the current investment. This money will be invested for a certain period of time called the investor's holding period. At the end of the holding period, the investor will sell the securities purchased at the beginning of the period and use the proceeds for consumptions or reinvestments in various securities (or perform both). Thus, this Markowitz approach can be viewed as a single approach. Markowitz stresses that investors usually expect not only high returns but also definite returns. It means that investors in their attempt to maximize the expectation of return and to minimize the uncertainty (risks) have 2 conflicting goals that must be balanced against each other when making a decision to buy securities. Returns and risks are related. To expect high returns, the risks expectation will also be high (Meredith, David, \& James, 2000).

Modern portfolio theory now become the main guidance in favor of portfolio allocation decisions for mutual funds, pension funds, and other institutions seeking for maximized portfolio investment returns and minimizing the risks. The modern portfolio theory explores how investors who avoid risks can form an optimal portfolio by regarding the exchange between market risks and 


\section{Jurnal Keuangan dan Perbankan | KEUANGAN}

Vol. 21, No. 4, Oktober 2017: 527-542

expectation of returns. The theory calculates the benefits of diversification. Investors can determine the efficient frontier of optimal portfolio. Each portfolio on the efficient frontier offers maximum return expectation on a certain level of risk. Investors can hold one optimal portfolio on efficient frontier by borrowing or lending government bonds that are risk-free securities.

\section{METHODS}

Asset diversification strategy (securities) through the establishment of a portfolio refers to Modern Portfolio Theory introduced by Markowitz (1952) and later refined by Markowitz (1959). Various methods of measuring portfolio performance that currently exist mostly refer to the theory developed by Markowitz (1952). Among the many instruments of portfolio performance measurements, Sharpe Index developed by Sharpe (1966), which was originally created to measure the performance of mutual funds in the United States, is the most common measuring instrument used and becomes standard for industry for its popularity. Moreover, Sharpe Index is also widely used by the financial industry because of its simplicity and facilitates practitioners and academicians in assessing a portfolio performance (Low \& Chin, 2013; Bednarek, Patel, \& Ramezani, 2014; Robiyanto, Wahyudi, \& Pangestuti, 2017). In terms of method, Sharpe Index is a measure that employs calculations of unit return minus risk-free rate of return compared to the total risk, commonly referred as reward to variability (Ferruz, Gómez-Bezares, \& Vargas, 2010). In other words, Sharpe Index emphasizes the portfolio performance measurement based on non-systematic risks.

Unlike Sharpe Index, Treynor (1965) introduced Treynor Ratio that calculates return per systematic risk unit. The Treynor Ratio formula measures return minus risk-free investment rate of return on each unit of market risks. This method of Treynor Ratio measure is often referred to as reward to volatility (Beer, Estes, \& Deshayes, 2011). Scholz \& Wilkens (2006) propose that both Sharpe Index and Treynor Ratio can be applied to rank the portfolio performances and to test for a well diversified portfolio (Robiyanto, 2017).

Jensen (1967) also creates a measurement instrument of portfolio performance which is often called Jensen Alpha. Based on the formula, Jensen Alpha is a special measure for risk-adjusted return of portfolio performance that specifically emphasizes on systematic risks. Sortino \& Price (1994) also take a role in modifying the existing instruments of measuring portfolio performance by developing Sortino Ratio. The basic idea of Sortino Ratio is to modify the Sharpe Index by utilizing downside deviation in lieu of standard deviation (Rollinger \& Hoffman, 2013). Sortino \& Price (1994) attempt to accommodate the argument suggested by Markowitz (1959) that only downside deviation is relevant for investors. Related to Jensen Alpha, Zulkafli, Ahmad, \& M. (2017) argues that Jensen Alpha is not appropriately used to measure performance at different performance levels. To overcome this issue, it is necessary to make adjustment to systematic risk factors. This adjustment is often called Adjusted Jensen Alpha (AJI).

Over time, those measurement instruments are not free of criticism, those instruments are even considered to have many disadvantages. Although its vast popularity, the Sharpe Index was not flawless. It been criticized by many scholars. Jobson \& Korkie (1981) stated that Sharpe Index have bias in the estimation of the standard deviation, while Bednarek, Patel, \& Ramezani (2014) arguing that Sharpe Index must used carefully according investment horizon. So it need adjusted before used to make a portfolio comparation. Jobson \& Korkie (1981), in an attempt to overcome the weakness of Sharpe Index that is considered as biased, conducted a modification of Sharpe Index which is then referred to as Adjusted Sharpe Index (ASI). While for the Jensen Alpha, according Zulkafli, 
Ahmad, M. (2017), Jensen Alpha is not appropriately used to measure performance at many different performance levels, hence need an adjustment according many different level of market risk. This adjustment must held in order to make better comparation (Kidd, 2011a).

Population of this study is all the equity mutual funds in Indonesia until the end of 2014 period. Not all members of the population are examined so that sampling is necessary. The samples are chosen by purposive sampling method with the following criterions: (1) active from 2012-2014; and (2) complete monthly data of Net Asset Value are available from 2012-2014.

Table 1. Sampling Derivation

\begin{tabular}{lr}
\hline \multicolumn{1}{c}{ Criterions } & N \\
\hline Total Stock Mutual Funds in the end of 2014 & 133 \\
Active from 2012-2014 & 91 \\
Missing data & 49 \\
Number of final samples & 42 \\
\hline
\end{tabular}

The sampling showed 42 equity mutual funds met the criteria. The list of samples are presented in Appendix 1. Data used in this study are as follows: (1) net asset value per unit of monthly period participation of each equity mutual fund sample from January 2012-December 2014, to calculate monthly return of equity mutual fund. The data were retrieved from the official website of each investment manager; (2) monthly SBI (Bank Indonesia Certificates) rate during 2012-2014, to calculate risk-free return $(R f)$. The data were obtained from Bank Indonesia; and (3) monthly closing of Composite Stock Price Index of Indonesia Stock Exchange Index during 2012-2014, to calculate market return $(\mathrm{Rm})$ of stock. The data were gathered from Indonesia Stock Exchange.

To calculate return of equity mutual funds studied here, the following formula is used:

$R_{N A V, t}=\left[\frac{N A V_{t}-N A V_{t-1}}{N A V_{t-1}}\right]$

\section{Where:}

$\mathrm{NAV}_{\mathrm{t}} \quad$ : net asset value of an equity mutual fund closing at month $\mathrm{t}$

$\mathrm{NAV}_{\mathrm{t}-1} \quad$ : net asset value of an equity mutual fund closing at month $\mathrm{t}-1$

This study uses several methods of portfolio performance measurements that include Sharpe Index, Treynor Ratio, Jensen Index, Sortino Ratio, Adjusted Sharpe Index, and Adjusted Jensen Index.

Performance measurement of equity mutual funds with Sharpe Index is done by the following formula (Sharpe, 1966):

Sharpe Ratio $=\frac{\text { Mean of Mutual Funds Returns }- \text { Risk Free Interest Rate }}{\text { Standard Deviation of Mutual Funds }}$

Performance measurement of equity mutual funds with Treynor Ratio is done by the following formula (Treynor, 1965):

Treynor Ratio $=\frac{\text { Mean of Mutual Funds Returns }- \text { Risk Free Interest Rate }}{\text {. }}$.

Performance measurement of equity mutual funds with Jensen Alpha $\left(\alpha_{i}\right)$ is calculated by the following formula:

$\propto=\left(R_{i, t}-R_{F} R_{t}\right)-\beta\left(R_{m, t}-R_{F} R_{t}\right)$

Where:

$R_{i, t} \quad$ : return of equity mutual fund at month $_{\mathrm{t}}$

$R F R_{t} \quad$ : risk-free interest rate at month

$R_{m, t} \quad$ : return of stock market (represented by CSPI return at month $_{\mathrm{t}}$

Performance measurement of equity mutual funds with Adjusted Sharpe Index (ASI) is calculated by:

ASI $=\mathrm{SI} \times \frac{\text { number of observations }(\mathrm{N})}{\text { number of observations }(\mathrm{N})+0.75}$ 


\section{Jurnal Keuangan dan Perbankan | KEUANGAN}

Vol. 21, No. 4, Oktober 2017: 527-542

Performance measurement of equity mutual funds with Adjusted Jensen Alpha Index (AJI) is calculated by the following formula:

$A J I=\frac{\text { Jensen Alpha }}{\text { BetaofPortfolio }}$

Performance measurement of equity mutual funds with Sortino Ratio (SoM) is calculated by:

SoM $=\frac{R_{i}-R F R_{t}}{\delta}$

Where, $\delta$ is downside deviation of equity mutual funds return rate at a certain period which is calculated with the following formula:

$\delta=\frac{\sqrt{\sum\left(\min R_{p}-M A R, O\right)^{2}}}{N-1}$

Where:

$\delta \quad$ : downside deviation

$R_{p} \quad$ : equity mutual funds return rate

MAR : minimum acceptable return $=$ risk free interest rate

$\mathrm{N} \quad$ : number of observations

With the provisions of:

If ( - MAR) marked negative, use ( - MAR)

If ( - MAR) marked positive, use 0

Risk-free rate is represented SBI return (interest rate) in 1 month period. After the results of Sharpe Index, Adjusted Sharpe Index, Treynor Ratio, Jensen Index, Adjusted Jensen Index, and Sortino Ratio found, those results will be sorted from highest value to the lowest value in order to know the best performer and the worst performer.

\section{RESULTS}

Based on the mean return and return premium, it is acquired that SAM Equity is able to produce the highest mean of return rate during 2012-2014 at 2.23 percent and generate return premium with 1.74 percent. Meanwhile, Prospera Bijak has mean of return with value mark at 0.02 percent and after being reduced with risk free return becomes 0.05 percent.

There are several equity mutual funds accounted premium return with negative sign, they are Prospera Bijak and Mandiri Investa Atraktif Syariah. It indicates that the 2 equity mutual funds provide lower return than the risk free investment instrument. The detail for each mutual fund returns is presented in Table 2.

From the standard deviation side, as shown in Table 3, Cipta Syariah Equity generates the lowest standard deviation with 0.0336 which indicates that the equity mutual funds formed from these stocks have the lowest risk compared to other funds. On the other hand, the highest standard deviation belongs to Pratama Saham with 0.0601 which implies that the risk of this fund is considered as relatively the highest when compared to other equity mutual funds studied here. Besides becoming a equity mutual fund with the lowest risk, according Table 4 Cipta Syariah Equity also generates the lowest beta portfolio with 0.6993 which indicates that the systematic risk of this fund is extremely low and it is also classified as defensive and is inelastic against stock market changes, on the contrary, Pratama Saham shows the highest total and, indeed, is the equity mutual fund with the biggest beta portfolio with 1.4659 which is considered as aggressive or sensitive against the stock market changes.

By using Sharpe Index as shown in Table 5, SAM Indonesian Equity is an equity mutual funds with the highest Sharpe Index (with value 0.3676), based on that SAM Indonesia Equity is the best among other equity mutual funds if measured by variability based return, conversely, Prospera Bijak the equity mutual funds with the worst performance compared to other equity mutual funds. Prospera Bijak showed Sharpe Index with the biggest negative signs (-0.0928). The other top 5 equity mutual funds are OSK Nusadana Alpha Sector (Sharpe Index: 0.2906), Cipta Syariah Equity (Sharpe Index: 0.2146), Pratama Saham (Sharpe Index: 0.1967), and BNP Paribas Infrastruktur Plus (Sharpe Index: 0.1849). 
Performance Evaluation of Equity Mutual Funds in Indonesia

Irene Rini Demi Pangestuti, Sugeng Wahyudi, Robiyanto Robiyanto

Table 2. Equity Mutual Fund's Ranking Base on Mean Return and Return Premium

\begin{tabular}{|c|c|c|}
\hline $\begin{array}{l}\text { Equity Mutual Fund's Name } \\
\end{array}$ & Mean Return & Mean (R-RF) \\
\hline Sam Indonesian Equity & 0.0223 & 0.0174 \\
\hline OSK Nusadana Alpha Sector Rotation & 0.0173 & 0.0124 \\
\hline Pratama Saham & 0.0167 & 0.0118 \\
\hline BNP Paribas Infrastruktur Plus & 0.0124 & 0.0076 \\
\hline Cipta Syariah Equity & 0.0121 & 0.0072 \\
\hline Tram Consumption Plus & 0.0117 & 0.0069 \\
\hline MNC Dana Ekuitas & 0.0112 & 0.0064 \\
\hline Schroder Dana Prestasi & 0.0111 & 0.0062 \\
\hline Trimegah Syariah Saham & 0.0111 & 0.0062 \\
\hline Dana Ekuitas Prima & 0.0108 & 0.0060 \\
\hline Batavia Dana Saham & 0.0107 & 0.0059 \\
\hline Panin Dana Prima & 0.0105 & 0.0057 \\
\hline Danareksa Mawar Konsumer 10 & 0.0105 & 0.0057 \\
\hline Batavia Dana Saham Syariah & 0.0102 & 0.0054 \\
\hline Syailendra Equity Opportunity & 0.0098 & 0.0049 \\
\hline TRIM Kapital & 0.0097 & 0.0049 \\
\hline Schroder Dana Istimewa & 0.0097 & 0.0049 \\
\hline AXA Citradinamis & 0.0097 & 0.0048 \\
\hline Manulife Syariah Sektoral Amanah & 0.0095 & 0.0047 \\
\hline First State IndoEquity Dividend Yield & 0.0094 & 0.0045 \\
\hline First State IndoEquity Peka & 0.0093 & 0.0044 \\
\hline Schroder 90 Plus Equity & 0.0091 & 0.0043 \\
\hline BNP Paribas Pesona & 0.0089 & 0.0041 \\
\hline BNP Paribas Ekuitas & 0.0088 & 0.0040 \\
\hline Mandiri Investa Ekuitas Dinamis & 0.0087 & 0.0039 \\
\hline Manulife Saham Andalan & 0.0086 & 0.0038 \\
\hline Manulife Dana Saham & 0.0086 & 0.0037 \\
\hline Mandiri Saham Atraktif & 0.0081 & 0.0033 \\
\hline Rencana Cerdas & 0.0081 & 0.0032 \\
\hline CIMB Principal Equity Aggressive & 0.0080 & 0.0032 \\
\hline Kresna Indeks 45 & 0.0078 & 0.0030 \\
\hline Schroder Dana Prestasi Plus & 0.0076 & 0.0028 \\
\hline First State IndoEquity Sectoral Fund & 0.0075 & 0.0026 \\
\hline Danareksa Mawar & 0.0071 & 0.0022 \\
\hline NISP Indeks Saham Progresif & 0.0069 & 0.0020 \\
\hline First State IndoEquity Value Select Fund & 0.0068 & 0.0020 \\
\hline Sinarmas Dana Saham & 0.0065 & 0.0016 \\
\hline TRIM Kapital Plus & 0.0065 & 0.0016 \\
\hline Mandiri Investra Atraktif & 0.0061 & 0.0012 \\
\hline Mandiri Investa UGM & 0.0052 & 0.0004 \\
\hline Mandiri Investa Atraktif Syariah & 0.0043 & $(0.0006)$ \\
\hline Prospera Bijak & $(0.0002)$ & $(0.0050)$ \\
\hline
\end{tabular}




\section{Jurnal Keuangan dan Perbankan | KEUANGAN}

Vol. 21, No. 4, Oktober 2017: 527-542

Table 3. Equity Mutual Fund's Ranking Based on Standard Deviation (STDEV)

\begin{tabular}{|c|c|c|c|c|c|}
\hline Rank & Equity Mutual Fund's Name & STDEV & Rank & Equity Mutual Fund's Name & STDEV \\
\hline 1 & Pratama Saham & 0.0601 & 22 & $\begin{array}{l}\text { OSK Nusadana Alpha Sector } \\
\text { Rotation }\end{array}$ & .0428 \\
\hline 2 & Mandiri Investa Ekuitas Dinamis & 0.0543 & 23 & Schroder Dana Istimewa & .0417 \\
\hline 3 & Prospera Bijak & 0.0541 & 24 & Schroder 90 Plus Equity & 0.0413 \\
\hline 4 & Sinarmas Dana Saham & 0.0536 & 25 & BNP Paribas Infrastruktur Plus & 0.0410 \\
\hline 5 & TRIM Kapital Plus & 0.0536 & 26 & Batavia Dana Saham & 0.0410 \\
\hline 6 & Mandiri Investa UGM & 0.0517 & 27 & $\begin{array}{l}\text { First State IndoEquity Value Select } \\
\text { Fund }\end{array}$ & 0.0409 \\
\hline 7 & CIMB Principal Equity Aggressive & 0.0481 & 28 & BNP Paribas Pesona & 0.0406 \\
\hline 8 & Panin Dana Prima & 0.0480 & 29 & BNP Paribas Ekuitas & 0.0405 \\
\hline 9 & Sam Indonesian Equity & 0.0474 & 30 & First State IndoEquity Peka & 0.0404 \\
\hline 10 & Dana Ekuitas Prima & 0.0472 & 31 & NISP Indeks Saham Progresif & 0.0403 \\
\hline 11 & Trimegah Syariah Saham & 0.0470 & 32 & Kresna Indeks 45 & 0.0400 \\
\hline 12 & Batavia Dana Saham Syariah & 0.0465 & 33 & Schroder Dana Prestasi & 0.0397 \\
\hline 13 & Rencana Cerdas & 0.0455 & 34 & $\begin{array}{l}\text { First State IndoEquity Dividend } \\
\text { Yield }\end{array}$ & 0.0394 \\
\hline 14 & Mandiri Investra Atraktif & 0.0455 & 35 & Schroder Dana Prestasi Plus & 0.0393 \\
\hline 15 & Syailendra Equity Opportunity & 0.0455 & 36 & Danareksa Mawar & 0.0393 \\
\hline 16 & Tram Consumption Plus & 0.0443 & 37 & Manulife Syariah Sektoral Amanah & 0.0393 \\
\hline 17 & TRIM Kapital & 0.0440 & 38 & First State IndoEquity Sectoral Fund & 0.0388 \\
\hline 18 & Manulife Saham Andalan & 0.0440 & 39 & AXA Citradinamis & 0.0387 \\
\hline 19 & Mandiri Saham Atraktif & 0.0436 & 40 & MNC Dana Ekuitas & 0.0385 \\
\hline 20 & Danareksa Mawar Konsumer 10 & 0.0436 & 41 & Manulife Dana Saham & 0.0368 \\
\hline 21 & Mandiri Investa Atraktif Syariah & 0.0435 & 42 & Cipta Syariah Equity & 0.0336 \\
\hline
\end{tabular}

Table 4. Equity Mutual Fund's Ranking Based on Beta

\begin{tabular}{|c|c|c|c|c|c|}
\hline Rank & Equity Mutual Fund's Name & Beta & Rank & Equity Mutual Fund's Name & Beta \\
\hline 1 & Pratama Saham & 1.4659 & 22 & BNP Paribas Pesona & 1.0952 \\
\hline 2 & Sinarmas Dana Saham & 1.3051 & 23 & BNP Paribas Ekuitas & 1.0907 \\
\hline 3 & TRIM Kapital Plus & 1.3051 & 24 & Schroder 90 Plus Equity & 1.0900 \\
\hline 4 & Mandiri Investa UGM & 1.2815 & 25 & Tram Consumption Plus & 1.0855 \\
\hline 5 & Mandiri Investa Ekuitas Dinamis & 1.2673 & 26 & First State IndoEquity Peka & 1.0819 \\
\hline 6 & Prospera Bijak & 1.2564 & 27 & $\begin{array}{l}\text { First State IndoEquity Value } \\
\text { Select Fund }\end{array}$ & 1.0801 \\
\hline 7 & CIMB Principal Equity Aggressive & 1.2200 & 28 & Schroder Dana Istimewa & 1.0782 \\
\hline 8 & Dana Ekuitas Prima & 1.2076 & 29 & Danareksa Mawar Konsumer 10 & 1.0677 \\
\hline 9 & Trimegah Syariah Saham & 1.2001 & 30 & Batavia Dana Saham & 1.0647 \\
\hline 10 & Mandiri Investra Atraktif & 1.1811 & 31 & $\begin{array}{l}\text { First State IndoEquity Dividend } \\
\text { Yield }\end{array}$ & 1.0509 \\
\hline 11 & Panin Dana Prima & 1.1810 & 32 & NISP Indeks Saham Progresif & 1.0495 \\
\hline 12 & Manulife Saham Andalan & 1.1590 & 33 & Kresna Indeks 45 & 1.0492 \\
\hline 13 & Syailendra Equity Opportunity & 1.1501 & 34 & Schroder Dana Prestasi Plus & 1.0460 \\
\hline 14 & Mandiri Saham Atraktif & 1.1478 & 35 & AXA Citradinamis & 1.0388 \\
\hline 15 & Batavia Dana Saham Syariah & 1.1414 & 36 & Danareksa Mawar & 1.0261 \\
\hline 16 & Sam Indonesian Equity & 1.1399 & 37 & Schroder Dana Prestasi & 1.0258 \\
\hline 17 & Rencana Cerdas & 1.1387 & 38 & $\begin{array}{l}\text { First State IndoEquity Sectoral } \\
\text { Fund }\end{array}$ & 1.0251 \\
\hline 18 & Mandiri Investa Atraktif Syariah & 1.1264 & 39 & $\begin{array}{l}\text { Manulife Syariah Sektoral } \\
\text { Amanah }\end{array}$ & 1.0084 \\
\hline 19 & $\begin{array}{l}\text { OSK Nusadana Alpha Sector } \\
\text { Rotation }\end{array}$ & 1.1107 & 40 & Manulife Dana Saham & 0.9787 \\
\hline 20 & TRIM Kapital & 1.1082 & 41 & MNC Dana Ekuitas & 0.9518 \\
\hline 21 & BNP Paribas Infrastruktur Plus & 1.0956 & 42 & Cipta Syariah Equity & 0.6993 \\
\hline
\end{tabular}


By using Adjusted Sharpe Index (ASI) as shown in Table 6, consistently SAM Indonesian Equity is an equity mutual funds with the highest Adjusted Sharpe Index (with value 0.3601), same with Sharpe Index measurement, Prospera Bijak is an equity mutual funds with the worst performance compared to other equity mutual funds. Prospera Bijak showed Adjusted Sharpe Index with the biggest negative signs (-0.0909). The sequence of top 5 equity mutual funds are consistent also, they are OSK Nusadana Alpha Sector (Sharpe Index: 0.2847), Cipta Syariah Equity (Sharpe Index: 0.2102), Pratama Saham (Sharpe Index: 0.1927), and BNP Paribas Infrastruktur Plus (Sharpe Index: 0.1812).
By using Treynor Ratio as shown in Table 7, SAM Indonesian Equity also become an equity mutual funds with the highest Treynor Ratio (with value 0.0153), based on that SAM Indonesia Equity is the best among other equity mutual funds if measured by volatility based return, conversely, the same condition also found on Prospera Bijak. Prospera Bijak is an equity mutual funds with the worst performance compared to other equity mutual funds. Prospera Bijak has Treynor Ratio with the biggest negative signs (-0.0040). The other top 5 equity mutual funds are OSK Nusadana Alpha Sector (Treynor Ratio: 0.0112), Cipta Syariah Equity (Treynor Ratio: 0.0103), Pratama Saham (Treynor Ratio: 0.0081), and BNP Paribas Infrastruktur Plus (Treynor Ratio: 0.0069).

Table 5. Equity Mutual Fund's Ranking Based on Sharpe Index

\begin{tabular}{|c|c|c|c|c|c|}
\hline Rank & Equity Mutual Fund's Name & $\begin{array}{l}\text { Sharpe } \\
\text { Index }\end{array}$ & Rank & Equity Mutual Fund's Name & $\begin{array}{l}\text { Sharpe } \\
\text { Index }\end{array}$ \\
\hline 1 & Sam Indonesian Equity & 0.3676 & 22 & Schroder 90 Plus Equity & 0.1034 \\
\hline 2 & $\begin{array}{l}\text { OSK Nusadana Alpha Sector } \\
\text { Rotation }\end{array}$ & 0.2906 & 23 & Manulife Dana Saham & 0.1014 \\
\hline 3 & Cipta Syariah Equity & 0.2146 & 24 & BNP Paribas Pesona & 0.1008 \\
\hline 4 & Pratama Saham & 0.1967 & 25 & BNP Paribas Ekuitas & 0.0976 \\
\hline 5 & BNP Paribas Infrastruktur Plus & 0.1849 & 26 & Manulife Saham Andalan & 0.0864 \\
\hline 6 & MNC Dana Ekuitas & 0.1653 & 27 & Mandiri Saham Atraktif & 0.0757 \\
\hline 7 & Schroder Dana Prestasi & 0.1572 & 28 & Kresna Indeks 45 & 0.0740 \\
\hline 8 & Tram Consumption Plus & 0.1554 & 29 & Mandiri Investa Ekuitas Dinamis & 0.0714 \\
\hline 9 & Batavia Dana Saham & 0.1433 & 30 & Rencana Cerdas & 0.0708 \\
\hline 10 & Trimegah Syariah Saham & 0.1326 & 31 & Schroder Dana Prestasi Plus & 0.0703 \\
\hline 11 & Danareksa Mawar Konsumer 10 & 0.1306 & 32 & $\begin{array}{l}\text { First State IndoEquity Sectoral } \\
\text { Fund }\end{array}$ & 0.0678 \\
\hline 12 & Dana Ekuitas Prima & 0.1271 & 33 & CIMB Principal Equity Aggressive & 0.0657 \\
\hline 13 & AXA Citradinamis & 0.1242 & 34 & Danareksa Mawar & 0.0572 \\
\hline 14 & Manulife Syariah Sektoral Amanah & 0.1194 & 35 & NISP Indeks Saham Progresif & 0.0499 \\
\hline 15 & Panin Dana Prima & 0.1187 & 36 & $\begin{array}{l}\text { First State IndoEquity Value Select } \\
\text { Fund }\end{array}$ & 0.0477 \\
\hline 16 & Schroder Dana Istimewa & 0.1167 & 37 & Sinarmas Dana Saham & 0.0305 \\
\hline 17 & $\begin{array}{l}\text { First State IndoEquity Dividend } \\
\text { Yield }\end{array}$ & 0.1154 & 38 & TRIM Kapital Plus & 0.0305 \\
\hline 18 & Batavia Dana Saham Syariah & 0.1153 & 39 & Mandiri Investra Atraktif & 0.0274 \\
\hline 19 & TRIM Kapital & 0.1109 & 40 & Mandiri Investa UGM & 0.0071 \\
\hline 20 & First State IndoEquity Peka & 0.1097 & 41 & Mandiri Investa Atraktif Syariah & $(0.0132)$ \\
\hline 21 & Syailendra Equity Opportunity & 0.1081 & 42 & Prospera Bijak & $(0.0928)$ \\
\hline
\end{tabular}




\section{Jurnal Keuangan dan Perbankan | KEUANGAN}

Vol. 21, No. 4, Oktober 2017: 527-542

By using Jensen Index as shown in Table 8, still SAM Indonesian Equity is an equity mutual funds with the highest Jensen Index (with value 0.0166), based on that SAM Indonesia Equity is the best among other equity mutual funds, on the contrary, Prospera Bijak is an equity mutual funds with the worst performance if measured by Jensen Index and compared to other equity mutual funds. Prospera Bijak showed Jensen Index with the biggest negative signs (-0.0060). By using Jensen Index, the sequence of other top 5 equity mutual funds are changing. The second best performer is OSK Nusadana Alpha Sector (Jensen Index: 0.0116), followed by Pratama Saham (Jensen Index: 0.0107),
BNP Paribas Infrastruktur Plus (Jensen Index: 0.0068), and Cipta Syariah Equity (Jensen Index: 0.0067).

By using Adjusted Jensen Index (AJI) as shown in Table 9, still SAM Indonesian Equity is an equity mutual funds with the highest Adjusted Jensen Index (with value 0.0145), based on that SAM Indonesia Equity is the best among other equity mutual funds, on the contrary, Prospera Bijak is an equity mutual funds with the worst performance if measured by Adjusted Jensen Index and compared to other equity mutual funds. Prospera Bijak showed Adjusted Jensen Index with the biggest negative signs (-0.0047).

Table 6. Equity Mutual Fund's Ranking Based on Adjusted Sharpe Index (ASI)

\begin{tabular}{|c|c|c|c|c|c|}
\hline Rank & Equity Mutual Fund's Name & ASI & Rank & Equity Mutual Fund's Name & ASI \\
\hline 1 & Sam Indonesian Equity & 0.3601 & 22 & Schroder 90 Plus Equity & 0.1013 \\
\hline 2 & $\begin{array}{l}\text { OSK Nusadana Alpha Sector } \\
\text { Rotation }\end{array}$ & 0.2847 & 23 & Manulife Dana Saham & 0.0993 \\
\hline 3 & Cipta Syariah Equity & 0.2102 & 24 & BNP Paribas Pesona & 0.0987 \\
\hline 4 & Pratama Saham & 0.1927 & 25 & BNP Paribas Ekuitas & 0.0956 \\
\hline 5 & BNP Paribas Infrastruktur Plus & 0.1812 & 26 & Manulife Saham Andalan & 0.0846 \\
\hline 6 & MNC Dana Ekuitas & 0.1620 & 27 & Mandiri Saham Atraktif & 0.0742 \\
\hline 7 & Schroder Dana Prestasi & 0.1540 & 28 & Kresna Indeks 45 & 0.0725 \\
\hline 8 & Tram Consumption Plus & 0.1522 & 29 & Mandiri Investa Ekuitas Dinamis & 0.0699 \\
\hline 9 & Batavia Dana Saham & 0.1404 & 30 & Rencana Cerdas & 0.0693 \\
\hline 10 & Trimegah Syariah Saham & 0.1299 & 31 & Schroder Dana Prestasi Plus & 0.0689 \\
\hline 11 & Danareksa Mawar Konsumer 10 & 0.1279 & 32 & $\begin{array}{l}\text { First State IndoEquity Sectoral } \\
\text { Fund }\end{array}$ & 0.0664 \\
\hline 12 & Dana Ekuitas Prima & 0.1245 & 33 & CIMB Principal Equity Aggressive & 0.0644 \\
\hline 13 & AXA Citradinamis & 0.1217 & 34 & Danareksa Mawar & 0.0560 \\
\hline 14 & Manulife Syariah Sektoral Amanah & 0.1169 & 35 & NISP Indeks Saham Progresif & 0.0489 \\
\hline 15 & Panin Dana Prima & 0.1163 & 36 & $\begin{array}{l}\text { First State IndoEquity Value Select } \\
\text { Fund }\end{array}$ & 0.0467 \\
\hline 16 & Schroder Dana Istimewa & 0.1144 & 37 & Sinarmas Dana Saham & 0.0299 \\
\hline 17 & $\begin{array}{l}\text { First State IndoEquity Dividend } \\
\text { Yield }\end{array}$ & 0.1130 & 38 & TRIM Kapital Plus & 0.0299 \\
\hline 18 & Batavia Dana Saham Syariah & 0.1129 & 39 & Mandiri Investra Atraktif & 0.0269 \\
\hline 19 & TRIM Kapital & 0.1086 & 40 & Mandiri Investa UGM & 0.0070 \\
\hline 20 & First State IndoEquity Peka & 0.1074 & 41 & Mandiri Investa Atraktif Syariah & $(0.0129)$ \\
\hline 21 & Syailendra Equity Opportunity & 0.1059 & 42 & Prospera Bijak & $(0.0909)$ \\
\hline
\end{tabular}


Performance Evaluation of Equity Mutual Funds in Indonesia

Irene Rini Demi Pangestuti, Sugeng Wahyudi, Robiyanto Robiyanto

Table 7. Equity Mutual Fund's Ranking Based on Treynor Ratio

\begin{tabular}{|c|c|c|c|c|c|}
\hline Rank & Equity Mutual Fund's Name & $\begin{array}{c}\text { Treynor } \\
\text { Ratio }\end{array}$ & Rank & Equity Mutual Fund's Name & $\begin{array}{c}\text { Treynor } \\
\text { Ratio } \\
\end{array}$ \\
\hline 1 & Sam Indonesian Equity & 0.0153 & 22 & Schroder 90 Plus Equity & 0.0039 \\
\hline 2 & OSK Nusadana Alpha Sector Rotation & 0.0112 & 23 & Manulife Dana Saham & 0.0038 \\
\hline 3 & Cipta Syariah Equity & 0.0103 & 24 & BNP Paribas Pesona & 0.0037 \\
\hline 4 & Pratama Saham & 0.0081 & 25 & BNP Paribas Ekuitas & 0.0036 \\
\hline 5 & BNP Paribas Infrastruktur Plus & 0.0069 & 26 & Manulife Saham Andalan & 0.0033 \\
\hline 6 & MNC Dana Ekuitas & 0.0067 & 27 & Mandiri Investa Ekuitas Dinamis & 0.0031 \\
\hline 7 & Tram Consumption Plus & 0.0063 & 28 & Mandiri Saham Atraktif & 0.0029 \\
\hline 8 & Schroder Dana Prestasi & 0.0061 & 29 & Rencana Cerdas & 0.0028 \\
\hline 9 & Batavia Dana Saham & 0.0055 & 30 & Kresna Indeks 45 & 0.0028 \\
\hline 10 & Danareksa Mawar Konsumer 10 & 0.0053 & 31 & Schroder Dana Prestasi Plus & 0.0026 \\
\hline 11 & Trimegah Syariah Saham & 0.0052 & 32 & CIMB Principal Equity Aggressive & 0.0026 \\
\hline 12 & Dana Ekuitas Prima & 0.0050 & 33 & First State IndoEquity Sectoral Fund & 0.0026 \\
\hline 13 & Panin Dana Prima & 0.0048 & 34 & Danareksa Mawar & 0.0022 \\
\hline 14 & Batavia Dana Saham Syariah & 0.0047 & 35 & NISP Indeks Saham Progresif & 0.0019 \\
\hline 15 & Manulife Syariah Sektoral Amanah & 0.0046 & 36 & $\begin{array}{l}\text { First State IndoEquity Value Select } \\
\text { Fund }\end{array}$ & 0.0018 \\
\hline 16 & AXA Citradinamis & 0.0046 & 37 & Sinarmas Dana Saham & 0.0013 \\
\hline 17 & Schroder Dana Istimewa & 0.0045 & 38 & TRIM Kapital Plus & 0.0013 \\
\hline 18 & TRIM Kapital & 0.0044 & 39 & Mandiri Investra Atraktif & 0.0011 \\
\hline 19 & First State IndoEquity Dividend Yield & 0.0043 & 40 & Mandiri Investa UGM & 0.0003 \\
\hline 20 & Syailendra Equity Opportunity & 0.0043 & 41 & Mandiri Investa Atraktif Syariah & $(0.0005)$ \\
\hline 21 & First State IndoEquity Peka & 0.0041 & 42 & Prospera Bijak & $(0.0040)$ \\
\hline
\end{tabular}

Table 8. Equity Mutual Fund's Ranking Based on Jensen Index

\begin{tabular}{|c|c|c|c|c|c|}
\hline Rank & Equity Mutual Fund's Name & $\begin{array}{l}\text { Jensen } \\
\text { Index }\end{array}$ & Rank & Equity Mutual Fund's Name & $\begin{array}{l}\text { Jensen } \\
\text { Index }\end{array}$ \\
\hline 1 & Sam Indonesian Equity & 0.0166 & 22 & Schroder 90 Plus Equity & 0.0034 \\
\hline 2 & OSK Nusadana Alpha Sector Rotation & 0.0116 & 23 & BNP Paribas Pesona & 0.0033 \\
\hline 3 & Pratama Saham & 0.0107 & 24 & BNP Paribas Ekuitas & 0.0031 \\
\hline 4 & BNP Paribas Infrastruktur Plus & 0.0068 & 25 & Manulife Dana Saham & 0.0030 \\
\hline 5 & Cipta Syariah Equity & 0.0067 & 26 & Manulife Saham Andalan & 0.0029 \\
\hline 6 & Tram Consumption Plus & 0.0061 & 27 & Mandiri Investa Ekuitas Dinamis & 0.0029 \\
\hline 7 & MNC Dana Ekuitas & 0.0056 & 28 & Mandiri Saham Atraktif & 0.0024 \\
\hline 8 & Schroder Dana Prestasi & 0.0055 & 29 & Rencana Cerdas & 0.0024 \\
\hline 9 & Trimegah Syariah Saham & 0.0053 & 30 & CIMB Principal Equity Aggressive & 0.0022 \\
\hline 10 & Dana Ekuitas Prima & 0.0051 & 31 & Kresna Indeks 45 & 0.0022 \\
\hline 11 & Batavia Dana Saham & 0.0051 & 32 & Schroder Dana Prestasi Plus & 0.0020 \\
\hline 12 & Danareksa Mawar Konsumer 10 & 0.0049 & 33 & First State IndoEquity Sectoral Fund & 0.0019 \\
\hline 13 & Panin Dana Prima & 0.0048 & 34 & Danareksa Mawar & 0.0015 \\
\hline 14 & Batavia Dana Saham Syariah & 0.0045 & 35 & NISP Indeks Saham Progresif & 0.0012 \\
\hline 15 & Schroder Dana Istimewa & 0.0041 & 36 & $\begin{array}{l}\text { First State IndoEquity Value Select } \\
\text { Fund }\end{array}$ & 0.0011 \\
\hline 16 & Syailendra Equity Opportunity & 0.0040 & 37 & Sinarmas Dana Saham & 0.0006 \\
\hline 17 & TRIM Kapital & 0.0040 & 38 & TRIM Kapital Plus & 0.0006 \\
\hline 18 & AXA Citradinamis & 0.0040 & 39 & Mandiri Investra Atraktif & 0.0004 \\
\hline 19 & Manulife Syariah Sektoral Amanah & 0.0039 & 40 & Mandiri Investa UGM & $(0.0006)$ \\
\hline 20 & First State IndoEquity Dividend Yield & 0.0037 & 41 & Mandiri Investa Atraktif Syariah & $(0.0014)$ \\
\hline 21 & First State IndoEquity Peka & 0.0036 & 42 & Prospera Bijak & $(0.0060)$ \\
\hline
\end{tabular}




\section{Jurnal Keuangan dan Perbankan | KEUANGAN}

Vol. 21, No. 4, Oktober 2017: 527-542

By using Adjusted Jensen Index, the sequence of other top 5 equity mutual funds are changing and differ from the Jensen Index's sequence. The second best performer is still OSK Nusadana Alpha Sector (Adjusted Jensen Index: 0.0104), followed by Cipta Syariah Equity (Adjusted Jensen Index: 0.0096), Pratama Saham (Adjusted Jensen Index: 0.0073), and BNP Paribas Infrastruktur Plus (Adjusted Jensen Index: 0.0062).

Surprisingly, by using Sortino Ratio as shown in Table 10, the sequence of 5 best performers are similar to the one which measured by Adjusted Jensen Index (AJI). SAM Indonesian Equity is an equity mutual funds with the highest Sortino Ratio (with value 0.6731). Consistenly, Prospera Bijak is an equity mutual funds with the worst performance compared to other equity mutual funds if measured by Sortino Ratio. Prospera Bijak showed Sortino Ratio with the biggest negative signs $(-0.1265)$. The second best performer is still OSK Nusadana Alpha Sector (Sortino Ratio: 0.4885), followed by Cipta Syariah Equity (Sortino Ratio: 0.3644), Pratama Saham (Sortino Ratio: 0.3288), and BNP Paribas Infrastruktur Plus (Sortino Ratio: 0.2843).

Table 9. Equity Mutual Fund's Ranking Based on Adjusted Jensen Index

\begin{tabular}{|c|c|c|c|c|c|}
\hline Rank & Equity Mutual Fund's Name & $\begin{array}{l}\text { Adjusted } \\
\text { Jensen } \\
\text { Index }\end{array}$ & Rank & Equity Mutual Fund's Name & $\begin{array}{c}\text { Adjusted } \\
\text { Jensen } \\
\text { Index }\end{array}$ \\
\hline 1 & Sam Indonesian Equity & 0.0145 & 22 & Schroder 90 Plus Equity & 0.0032 \\
\hline 2 & $\begin{array}{l}\text { OSK Nusadana Alpha Sector } \\
\text { Rotation }\end{array}$ & 0.0104 & 23 & Manulife Dana Saham & 0.0031 \\
\hline 3 & Cipta Syariah Equity & 0.0096 & 24 & BNP Paribas Pesona & 0.0030 \\
\hline 4 & Pratama Saham & 0.0073 & 25 & BNP Paribas Ekuitas & 0.0029 \\
\hline 5 & BNP Paribas Infrastruktur Plus & 0.0062 & 26 & Manulife Saham Andalan & 0.0025 \\
\hline 6 & MNC Dana Ekuitas & 0.0059 & 27 & Mandiri Investa Ekuitas Dinamis & 0.0023 \\
\hline 7 & Tram Consumption Plus & 0.0056 & 28 & Mandiri Saham Atraktif & 0.0021 \\
\hline 8 & Schroder Dana Prestasi & 0.0053 & 29 & Rencana Cerdas & 0.0021 \\
\hline 9 & Batavia Dana Saham & 0.0048 & 30 & Kresna Indeks 45 & 0.0021 \\
\hline 10 & Danareksa Mawar Konsumer 10 & 0.0046 & 31 & Schroder Dana Prestasi Plus & 0.0019 \\
\hline 11 & Trimegah Syariah Saham & 0.0044 & 32 & CIMB Principal Equity Aggressive & 0.0018 \\
\hline 12 & Dana Ekuitas Prima & 0.0042 & 33 & First State IndoEquity Sectoral Fund & 0.0018 \\
\hline 13 & Panin Dana Prima & 0.0041 & 34 & Danareksa Mawar & 0.0014 \\
\hline 14 & Batavia Dana Saham Syariah & 0.0039 & 35 & NISP Indeks Saham Progresif & 0.0012 \\
\hline 15 & Manulife Syariah Sektoral Amanah & 0.0039 & 36 & $\begin{array}{l}\text { First State IndoEquity Value Select } \\
\text { Fund }\end{array}$ & 0.0011 \\
\hline 16 & AXA Citradinamis & 0.0039 & 37 & Sinarmas Dana Saham & 0.0005 \\
\hline 17 & Schroder Dana Istimewa & 0.0038 & 38 & TRIM Kapital Plus & 0.0005 \\
\hline 18 & TRIM Kapital & 0.0036 & 39 & Mandiri Investra Atraktif & 0.0003 \\
\hline 19 & $\begin{array}{l}\text { First State IndoEquity Dividend } \\
\text { Yield }\end{array}$ & 0.0036 & 40 & Mandiri Investa UGM & $(0.0005)$ \\
\hline 20 & Syailendra Equity Opportunity & 0.0035 & 41 & Mandiri Investa Atraktif Syariah & $(0.0013)$ \\
\hline 21 & First State IndoEquity Peka & 0.0033 & 42 & Prospera Bijak & $(0.0047)$ \\
\hline
\end{tabular}




\section{DISCUSSION}

This study found that equity mutual funds formed from the sharia stocks such as Cipta Syariah Equity, Manulife Syariah Sektor Amanah, Mandiri Investa Atraktif Syariah, Batavia Dana Saham Syariah, Trimegah Syariah Saham were infact able to produce lower risks compared to the other equity mutual funds. Equity mutual funds with the highest risk are dominated by the conventional equity mutual funds. These findings support a research result by Robiyanto (2017) which revealed that the sharia stocks tend to have lower risks than the other stocks and is consistent to the research by Qomariah, Sari, \& Budiarti (2016).

The analysis showed that in general there is a consistency among the measurement instruments of portfolio performance by employing Sharpe Index, Adjusted Sharpe Index, Treynor Ratio,
Jensen Index, Adjusted Jensen Index, and Sortino Ratio, then it is revealed that almost all equity mutul funds have a consistent rate. For example, consistently SAM Indonesia Equity become the best performer when measured by Sharpe Index, Adjusted Sharpe Index, Treynor Ratio, Jensen Index, Adjusted Jensen Index, and Sortino Ratio. While the other member of top 5 performer only differ slightly in sequential manner but the top 5 performer are SAM Indonesia Equity, OSK Nusadana Alpha Sector, Cipta Syariah Equity, Pratama Saham and BNP Paribas Infrastruktur Plus. The usage of risk based measurement is more apprioriate than return comparison, since according Markowitz (1952), the aim of the portfolio is to provides the highest return for a given level of risk.

The findings also shows that by using Sharpe Index and Adjusted Sharpe Index (ASI), the se-

Table 10. Equity Mutual Fund's Ranking Based on Sortino Ratio

\begin{tabular}{|c|c|c|c|c|c|}
\hline Rank & Equity Mutual Fund's Name & $\begin{array}{c}\text { Sortino } \\
\text { Ratio } \\
\end{array}$ & Rank & Equity Mutual Fund's Name & $\begin{array}{c}\text { Sortino } \\
\text { Ratio }\end{array}$ \\
\hline 1 & Sam Indonesian Equity & 0.6731 & 22 & Manulife Dana Saham & 0.1514 \\
\hline 2 & $\begin{array}{l}\text { OSK Nusadana Alpha Sector } \\
\text { Rotation }\end{array}$ & 0.4885 & 23 & Schroder 90 Plus Equity & 0.1493 \\
\hline 3 & Cipta Syariah Equity & 0.3644 & 24 & BNP Paribas Pesona & 0.1456 \\
\hline 4 & Pratama Saham & 0.3288 & 25 & BNP Paribas Ekuitas & 0.1407 \\
\hline 5 & BNP Paribas Infrastruktur Plus & 0.2843 & 26 & Manulife Saham Andalan & 0.1260 \\
\hline 6 & MNC Dana Ekuitas & 0.2725 & 27 & Kresna Indeks 45 & 0.1116 \\
\hline 7 & Schroder Dana Prestasi & 0.2406 & 28 & Rencana Cerdas & 0.1073 \\
\hline 8 & Tram Consumption Plus & 0.2348 & 29 & Mandiri Saham Atraktif & 0.1056 \\
\hline 9 & Batavia Dana Saham & 0.2189 & 30 & Mandiri Investa Ekuitas Dinamis & 0.1032 \\
\hline 10 & Trimegah Syariah Saham & 0.1991 & 31 & $\begin{array}{l}\text { First State IndoEquity Sectoral } \\
\text { Fund }\end{array}$ & 0.1014 \\
\hline 11 & Danareksa Mawar Konsumer 10 & 0.1910 & 32 & Schroder Dana Prestasi Plus & 0.1014 \\
\hline 12 & Manulife Syariah Sektoral Amanah & 0.1899 & 33 & CIMB Principal Equity Aggressive & 0.0918 \\
\hline 13 & AXA Citradinamis & 0.1869 & 34 & Danareksa Mawar & 0.0865 \\
\hline 14 & Dana Ekuitas Prima & 0.1849 & 35 & NISP Indeks Saham Progresif & 0.0751 \\
\hline 15 & Batavia Dana Saham Syariah & 0.1789 & 36 & $\begin{array}{l}\text { First State IndoEquity Value Select } \\
\text { Fund }\end{array}$ & 0.0717 \\
\hline 16 & Panin Dana Prima & 0.1765 & 37 & Sinarmas Dana Saham & 0.0442 \\
\hline 17 & $\begin{array}{l}\text { First State IndoEquity Dividend } \\
\text { Yield }\end{array}$ & 0.1743 & 38 & TRIM Kapital Plus & 0.0442 \\
\hline 18 & Schroder Dana Istimewa & 0.1716 & 39 & Mandiri Investra Atraktif & 0.0374 \\
\hline 19 & First State IndoEquity Peka & 0.1640 & 40 & Mandiri Investa UGM & 0.0099 \\
\hline 20 & Syailendra Equity Opportunity & 0.1601 & 41 & Mandiri Investa Atraktif Syariah & $(0.0181)$ \\
\hline 21 & TRIM Kapital & 0.1555 & 42 & Prospera Bijak & $(0.1265)$ \\
\hline
\end{tabular}




\section{Jurnal Keuangan dan Perbankan | KEUANGAN}

Vol. 21, No. 4, Oktober 2017: 527-542

quence of the best performers to the worst performers do not change at all. The different sequence occurs when using Jensen Index and Adjusted Jensen Index. By using Adjusted Jensen Index which use beta as a proxy of market risk, Adjusted Jensen Alpha expected can produce fair comparation between each portofolio (Kidd, 2011a), this study find that there are inconsistency between the ranking result by using Jensen Index and Adjusted Jensen Index (AJI). The higher Jensen Index would not guarantee the higher Adjusted Jensen Index if the market risk (beta) also higher. But the lower Jensen Index with lower market risk (beta) could led the higher Adjusted Jensen Index. This measurement sound fair enough to make portfolio's performance comparation, as evidenced in this study.

Overall, this study also indicates that the equity mutual funds studied are in general have been well diversified. This result is in line with Pratomo (2001) which suggests that the portfolios which are well diversified will tend to have a consistent rate between the Sharpe Index and the Treynor Ratio.

\section{CONCLUSION AND SUGGESTIONS}

\section{Conclusion}

The result shows that not all of the equity mutual funds studied is able to produce premium return with positive sign. It implies that the performance of those equity mutual funds is no better than the risk-free investment instruments. It further found that the sharia equity mutual funds tend to possess a lower risk rate compared to the conventional ones when seen from the standard deviation.

In general, it is concluded that most of the equity mutual funds under this study are already well diversified for they have consistency in performance rate when measured with Sharpe Index and Treynor Ratio. This study also reveals that the equity mutual funds of SAM Indonesian Eq- uity comes as the best performer during the research period with the highest score of Sharpe Index, Adjusted Sharpe Index, Treynor Ratio, Jensen Index, Adjusted Jensen Index, and Sortino Ratio. This study also found that higher risk do not associated automatically with risk based return (i.e. reward based volatility and reward based variability), since some mutuals fund could produce superior return with better diversification strategy.

\section{Suggestions}

Since the SAM Indonesian Equity comes as the best performer during the research period with the highest score of Sharpe Index, Adjusted Sharpe Index, Treynor Ratio, Jensen Index, Adjusted Jensen Index, and Sortino Ratio, so investors who are interested to invest in equity mutual funds as the investment instrument with growth orientation may choose SAM Indonesian Equity. Whereas, investors who expect investment instrument with safe growth, trusted, and based on sharia may invest in sharia equity mutual funds since it has a lower risk rate. Meanwhile, mutual fund's investment manager especially for mutual fund with worst performance, should reformulate their investment strategy in order to obtain better performance.

For future research agenda, researchers who are interested to conduct research in the same field may use instruments of measuring portfolio performance that have not been utilized in this study such as Information Ratio. It is also suggested to study per investment manager and use other indicators such as the existing managed funds.

\section{REFERENCES}

Arisonda, E. (2013). Analisis perbandingan kinerja portofolio saham dengan metode Sharpe, Treynor, dan Jensen (Studi kasus indeks LQ 45 di Bursa Efek Indonesia periode 2008-2012). Jurnal Dinamika Manajemen, 1(4). 


\section{Performance Evaluation of Equity Mutual Funds in Indonesia}

Irene Rini Demi Pangestuti, Sugeng Wahyudi, Robiyanto Robiyanto

Bednarek, Z., Patel, P., \& Ramezani, C. (2014). Sharpe ratio over investment horizon. Working Paper.

Beer, F. M., Estes, J. P., \& Deshayes, C. (2011). The performance of faith and ethical investment products: An empirical investigation of the last decade. Journal of the Academy of Business and Economics, 30, 101-124.

Cvitanic, J., Lazrak, A., \& Wang, T. (2007). Implications of sharpe ratio as a performance measure in multiperiod settings. Working Paper.

Ferruz, L., Gómez-Bezares, F., \& Vargas, M. (2010). Portfolio theory, CAPM, and performance measures. Handbook of Quantitative Finance and Risk Management, 267-281.

Jensen, M. C. (1967). The performance of mutual funds in the period 1945-1964. Journal of Finance, 23(2), 389416. http://dx.doi.org/10.2139/ssrn.244153

Jobson, J. D., \& Korkie, B. M. (1981). Performance hypothesis testing with the Sharpe and Treynor measures. Journal of Finance, 36(4), 889-908. doi: 10.1111/ j.1540-6261.1981.tb04891.x

Kidd, D. (2011a). Measures of risk-adjusted return: let's not forget Treynor and Jensen. Investment Performance Measurement Feature Articles, (1).

Kidd, D. (2011b). The sharpe ratio and the information ratio. Investment Performance Measurement Feature Articles, 1, 1-4. doi: http:/ / www.cfapubs.org/doi/ pdf/10.2469/ipmn.v2011.n1.7

Kidd, D. (2012). Risk-adjusted performance measures: a case study. Investment Risk and Performance, 1, 1-4.

Low, S.-W., \& Chin, Y.-B. (2013). Refinements to the sharpe ratio-evidence from malaysian equity funds. Global Economic Review, 42(1), 72-97. doi: http:// dx.doi.org/10.1080/1226508X.2013.769818

Markowitz, H. M. (1952). Portfolio selection. Journal of Finance, 7(1), 77-91. doi: http://dx.doi.org/ 10.1111/j.1540-6261.1952.tb01525.x

Markowitz, H. M. (1959). Portfolio Selection: Efficient Diversification of Investments. New York: John Wiley \& Sons, Inc.

Meredith, B., David, G., \& James, V. (2000). The efficient market hypothesis: A survey. Working Paper Economic Research Department Reserve Bank of Australia.
Pav, S. E. (2016). Notes on the sharpe ratio. Working Paper.

Pratomo, E. P. (2001). Reksa dana: solusi perencanaan investasi di era modern. Jakarta: Gramedia Pustaka Utama.

Qomariah, N., Sari, M. I., \& Budiarti, D. A. (2016). Perbandingan kinerja reksadana syariah dan reksadana konvensional (pada reksadana saham dan reksadana pendapatan tetap yang terdaftar di BEI periode 2010-2014). Jurnal Keuangan dan Perbankan, 20(3), 417-427.

Robiyanto, R. (2017). Performance evaluation and risk aversion rate for several stock indices in indonesia stock exchange. Jurnal Manajemen dan Kewirausahaan, 19(1), 60-64. doi: 10.9744/ jmk.19.1.60-64

Robiyanto, R., Wahyudi, S., \& Pangestuti, I.R.D. (2017). The Volatility-variability hypotheses testing and hedging effectiveness of precious metals for the indonesian and malaysian capital markets. Gadjah Mada International Journal of Business, 19(2), 167192. doi: https://doi.org/10.22146/gamaijb. 26260

Rollinger, T. N., \& Hoffman, S. T. (2013). Sortino: a 'sharper'ratio. Chicago: Red Rock Capital. http:// www.redrockcapital.com/assets/RedRock_ Sortino_white_paper.pdf

Scholz, H., \& Wilkens, M. (2006). Investor-specific performance measurement - a justification of sharpe ratio and treynor ratio. Working Paper.

Sharpe, W. F. (1966). Mutual fund performance. Journal of Business, 39(1), 119-138. doi: http://dx.doi.org/ $10.1086 / 294846$

Simanjuntak, T. M. (2012). Analisis kinerja reksa dana saham menggunakan metode Sharpe, Treynor, dan Jensen. Master Thesis. Universitas Gadjah Mada Yogyakarta.

Simforianus, S., \& Hutagaol, Y. (2008). Analisis kinerja reksa dana saham dengan metode raw return, Sharpe, Treynor, Jensen, dan Sortino. Journal of Applied Finance and Accounting, 1(1), 193-226.

Sortino, F. A., \& Price, L. N. (1994). Performance measurement in a downside risk framework. Journal of Investing, 3(3), 59-64. doi: 10.3905/joi.3.3.59 


\section{Jurnal Keuangan dan Perbankan | KEUANGAN}

Vol. 21, No. 4, Oktober 2017: 527-542

Swinkels, L., \& Rzezniczak, P. (2009). Performance evaluation of polish mutual fund managers. International Journal of Emerging Markets, 4(1), 26-42. doi: 10.1108/17468800910931652

Treynor, J. L. (1965). How to rate management of investment funds. Harvard Business Review, 43(1), 63-75.
Zulkafli, A. H., Ahmad, Z., \& M., E. E. (2017). The performance of socially responsible investments in Indonesia: A study of the Sri Kehati Index (SKI). Gadjah Mada International Journal of Business, 19(1), 59-76. https://doi.org/10.22146/gamaijb.17959 